\title{
Simulation of heat losses and temperature of blast furnaces tuyeres
}

\author{
Yuriy Tarasov ${ }^{1, *}$, Alexandr Radyuk ${ }^{1}$, and Sergey Gorbatyuk ${ }^{1}$ \\ ${ }^{1}$ EDP Sciences, National University of Science and Technology «MISiS», Moscow, Russian Federation
}

\begin{abstract}
The calculation technique of heat losses and temperature, adapted to blast furnaces tuyeres is described. Using a linear excel program the effect of gas-thermal coating and insulation lining on thermal state of the blast tuyere was studied. Problems of the blast tuyeres hardening and reducing heat losses through their surface are relevant, but finding ways of the blast tuyeres hardening and reducing heat losses through their surface by simulation of the thermal state of blast furnaces tuyeres are carried out. Key words: blast tuyere, blast furnace, tuyere nose, air passage, internal nozzle, gas-thermal coating, insulation lining.
\end{abstract}

\section{Introduction}

Blast tuyere is a key constructional element of blast furnace, determining its running efficiency. For this reason the furnace downtime leads to considerable reduction of iron smelting and increasing coke consumption. Besides, blast tuyeres account for $30 \%$ of all heat losses in furnance. So the problems of the blast tuyeres' hardening and reducing heat losses through their surface are relevant. While under normal condition of blast-furnace operation through a tuyere nose, external and internal nozzles of tuyeres flow 18, 36 and 46\% respectively [1].

At the present time the given problems are solved by different ways: applying gas-flame sprayed coatings on an external surface of tuyere and lining-up by firebrick from the direction of air passage [2], applying heat-resisting backfill on an external surface of tuyere $[3,4]$ and others.

For further thinking on the ways of the blast tuyeres' hardening and reducing heat losses through their surface, simulation of thermal state of blast furnaces tuyeres is useful [5-7].

Let us use a calculation procedure of heat losses through blast tuyere [8]. In work the steady heat conduction formulae for flat and cylindrical wall were used $[9,10]$.

\section{Research technique and results}

Heat transfer through tuyeres surface is:

$$
\begin{aligned}
& Q=Q_{n}+Q_{r}+Q_{d}=Q_{n}+Q_{r n}+Q_{r t}+Q_{v}+Q_{r v}= \\
& K_{n}^{*} \cdot\left(t_{g}-t_{v}\right) \cdot H_{n}+K_{r n}^{*}\left(t_{g}-t_{v}\right) \cdot\left(H_{r n}-h_{r t}\right)+K_{r t} . \\
&\left(t_{g}-t_{v}\right) \cdot S_{r t}+K_{v}^{*} \cdot\left(t_{d}-t_{v}\right) \cdot H_{v}+K_{r v}^{*} \cdot\left(t_{d}-t_{v}\right) . \\
&\left(H_{r v}-h_{r t}\right) .
\end{aligned}
$$

where $Q_{n}, Q_{r}, Q_{d}$ is the heat transfer through external nozzle, tuyere nose (from outside and cross-cut end) and from side of air passage respectively, $\mathrm{W}$;

$Q_{\mathrm{rn}}, \mathrm{Q}_{\mathrm{rt}}, \mathrm{Q}_{\mathrm{v}}, \mathrm{Q}_{\mathrm{rv}}$ is the heat transfer through external surface of tuyere nose, butt end of tuyere nose, internal nozzle and tuyere nose from side of air passage respectively, $\mathrm{W}$;

$\mathrm{K}_{\mathrm{n}}^{*}, \mathrm{~K}_{\mathrm{rn}}^{*}, \mathrm{~K}_{\mathrm{v}}^{*}, \mathrm{~K}_{\mathrm{rv}}^{*}$ is the testing heat-transfer rate through external nozzle, external surface of tuyere nose, internal nozzle of tuyere and tuyere nose from the side of air passage respectively, $\mathrm{W} /(\mathrm{m} \cdot \mathrm{K})$;

$\mathrm{K}_{\mathrm{rt}}$ is the heat-transfer rate through butt end of tuyere nose, $\mathrm{W} /(\mathrm{m} 2 \cdot \mathrm{K})$;

$t_{g}, t_{d}$ is tuyere temperature in iron receiver and hot blast temperature respectively, ${ }^{\circ} \mathrm{C}$;

$\mathrm{t}_{\mathrm{v}}$ is water temperature in tuyere, ${ }^{\circ} \mathrm{C}$;

$\mathrm{H}_{\mathrm{n}}, \mathrm{H}_{\mathrm{v}}, \mathrm{H}_{\mathrm{rn}}, \mathrm{H}_{\mathrm{rv}}$ is the length of external nozzle, internal nozzle, nose outside tuyere and tuyere nose from the side of air passage respectively (fig.1), m;

$\mathrm{h}_{\mathrm{rt}}$ is the thickness of cross-cut end of tuyere nose (fig. 1), m;

$\mathrm{S}_{\mathrm{rt}}$ is the area of butt end of tuyere nose, $\mathrm{m}^{2}$.

$$
=\frac{K_{n}^{*}}{\frac{1}{\alpha_{g n} \cdot R_{n}^{*}}+\sum_{i=1}^{m} \frac{1}{\lambda_{i}} \cdot \ln \frac{R_{n j}}{R_{n j+1}}+\frac{1}{\lambda_{C u}} \cdot \ln \frac{R_{n}}{R_{n}-h_{n}}+\frac{1}{\alpha_{v} \cdot\left(R_{n}-h_{n}\right)}}
$$

where $\alpha_{g n}$ is coefficient of heat-exchange to external nozzle from gas forge, $\mathrm{W} /(\mathrm{m} 2 \cdot \mathrm{K})$;

$$
\begin{gathered}
R_{I}^{*}=R_{I}+\sum_{i=1}^{m} h_{i}, \grave{\imath} \\
R_{I 1}=R_{I}^{*}, \grave{\imath} \\
R_{I_{j}}=R_{I}^{*}-\sum_{i=1}^{j-1} h_{i}, \grave{l}
\end{gathered}
$$

\footnotetext{
*Corresponding author: trsi@mail.ru
} 


$$
\begin{gathered}
R_{\hat{I}_{j+1}}=R_{I}^{*}-\sum_{i=1}^{j} h_{i}, \grave{ } \\
j=1, \ldots m
\end{gathered}
$$

$R_{n}$ is the midradius of external nozzle from the side of furnace, $\mathrm{m}$;

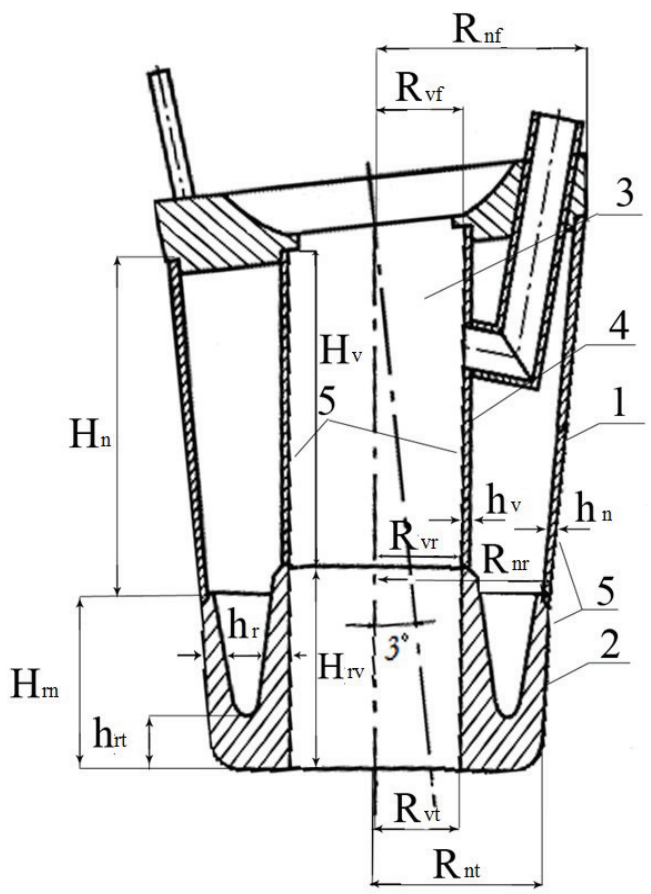

Fig. 1. Longitudinal section of blast tuyere:1- external nozzle, 2- tuyere nose,3- air passage, 4- internal nozzle, 5- covering

$$
R_{n}=\frac{R_{n r}+R_{n f}}{2}
$$

$R_{n r}, R_{n f}$ is the radius of external nozzle from the side of furnace against tuyere nose and flange respectively (fig.1), m;

$h_{n}, h_{i}$ is the thickness of external nozzle and i- coating material respectively (fig. 1), m;

$\lambda_{C u}, \lambda_{i}$ is the heat conduction coefficient of cuprum $\mathrm{M} 1$ and i-coating material respectively $\mathrm{W} /(\mathrm{m} \cdot \mathrm{K})$;

$\mathrm{m}$ is the allotment of covering materials (layers);

$\alpha_{v}$ is the coefficient of heat-transfer from tuyere wall to water, $\mathrm{W} /\left(\mathrm{m}^{2} \cdot \mathrm{K}\right)$.

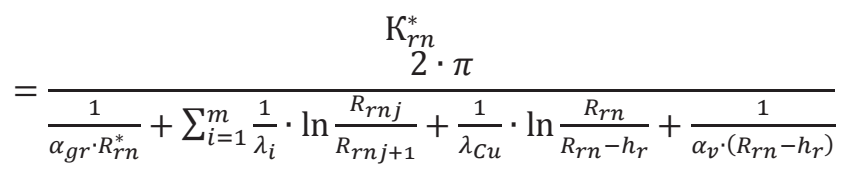

where $\alpha_{g r}$ is the coefficient of heat-transfer of tuyere nose from gas forge $\mathrm{W} /\left(\mathrm{m}^{2} \cdot \mathrm{K}\right)$;

$$
\begin{gathered}
R_{r n}^{*}=R_{r n}+\sum_{i=1}^{m} h_{i} \\
R_{r n 1}=R_{r n}^{*} \\
R_{r n j}=R_{r n}^{*}-\sum_{i=1}^{j-1} h_{i}
\end{gathered}
$$

$$
\begin{gathered}
R_{r n j+1}=R_{r n}^{*}-\sum_{i=1}^{j} h_{i} \\
j=1, \ldots m
\end{gathered}
$$

$R_{r n}$ is the midradius of tuyere nose from the side of furnace, $\mathrm{m}$;

$$
R_{r n}=\frac{R_{n r}+R_{n t}}{2}
$$

$R_{n t}$ is the radius of tuyere nose against tuyere's crosscut end (fig. 1), m;

$h_{r}$ is the average thickness of tuyere nose without butt end thickness considering, $\mathrm{m}$.

$$
\mathrm{K}_{r t}=\frac{1}{\frac{1}{\alpha_{g r}}+\sum_{i=1}^{m} \frac{h_{i}}{\lambda_{i}}+\frac{h_{r t}}{\lambda_{C u}}+\frac{1}{\alpha_{v}}}
$$

where $h_{r t}$ is the thickness of cross-cut end of tuyere nose, $\mathrm{m}$.

$$
=\frac{2 \cdot \pi}{\frac{1}{\alpha_{d} \cdot R_{v}^{*}}+\sum_{i=1}^{m} \frac{1}{\lambda_{i}} \cdot \ln \frac{R_{v j+1}}{R_{v j}}+\frac{1}{\lambda_{C u}} \cdot \ln \frac{R_{v}+h_{v}}{R_{v}}+\frac{1}{\alpha_{v} \cdot\left(R_{v}+h_{v}\right)}}
$$

where $\alpha_{d}$ is the coefficient of heat-transfer from hot blow to tuyere wall, $\mathrm{W} /\left(\mathrm{m}^{2} \cdot \mathrm{K}\right)$;

$$
\begin{gathered}
R_{v}^{*}=R_{v}-\sum_{i=1}^{m} h_{i} \\
R_{v 1}=R_{v}^{*} \\
R_{v j}=R_{v}^{*}+\sum_{i=1}^{j-1} h_{i} \\
R_{v j+1}=R_{v}^{*}+\sum_{i=1}^{j} h_{i} \\
j=1, \ldots m \\
R_{v}=\frac{R_{v r}+R_{v f}}{2}
\end{gathered}
$$

$R_{v r}, R_{v f}$ is the radius of internal nozzle from the side of air passage against tuyere nose and flange respectively (fig.1), m;

$h_{v}$ is the thickness of internal nozzle (fig.1), m.

$$
=\frac{\kappa_{r v}^{*}}{\frac{1}{\alpha_{d} \cdot R_{r v}^{*}}+\sum_{i=1}^{m} \frac{1}{\lambda_{i}} \cdot \ln \frac{R_{r n j+1}}{R_{r v j}}+\frac{1}{\lambda_{C u}} \cdot \ln \frac{R_{r v}+h_{r}}{R_{r v}}+\frac{1}{\alpha_{v} \cdot\left(R_{r v}+h_{r}\right)}}
$$

where,

$$
\begin{gathered}
R_{r v}^{*}=R_{r v}-\sum_{i=1}^{m} h_{i} \\
R_{r v 1}=R_{r v}^{*} \\
R_{r v j}=R_{r v}^{*}+\sum_{i=1}^{j-1} h_{i}
\end{gathered}
$$




$$
\begin{aligned}
R_{r v j+1} & =R_{r v}^{*}+\sum_{i=1}^{j} h_{i} \\
j & =1, \ldots m \\
R_{r v} & =\frac{R_{v r}+R_{v t}}{2}
\end{aligned}
$$

$R_{v t}$ is the radius of air passage against cross-cut end of tuyere (fig. 1), m.

$$
S_{r t}=\pi \cdot\left(R_{n t}^{2}-R_{v t}^{2}\right)
$$

Methods of temperature calculation on different surfaces of blast tuyere with using steady heat conduction formulae through a cylindrical and flat multiple-layer wall is as follows [10]:

-For external nozzle:

Temperature on the surface of the first coating's layer from the side of furnace is:

$$
t_{g-1}=t_{g}-\frac{K_{n}^{*} \cdot\left(t_{g}-t_{v}\right)}{2 \pi \cdot \alpha_{g n} \cdot R_{n}^{*}}
$$

Temperature at the joint of $j$ and $j+1$ coating`s layers or coating`s layer and external nozzle:

$t_{j, j+1}=$
$=\frac{K_{n}^{*} \cdot\left(t_{g}-t_{v}\right)}{2 \pi} \cdot\left(\frac{1}{\alpha_{g n} \cdot R_{n}^{*}}+\sum_{i=1}^{j} \frac{1}{\lambda_{i}} \cdot \ln \frac{R_{n j}}{R_{n j+1}}\right)$

Temperature on the surface of external nozzle from the side of water is:

$$
t_{n-v}=t_{v}+\frac{K_{n}^{*} \cdot\left(t_{g}-t_{v}\right)}{2 \pi \cdot \alpha_{v} \cdot\left(R_{n}-h_{n}\right)}
$$

- For tuyere nose from the furnaces side:

Temperature on the surface of the first coating's layer from the side of furnace is:

$$
t_{g-1}=t_{g}-\frac{\mathrm{K}_{r n}^{*} \cdot\left(t_{g}-t_{v}\right)}{2 \pi \cdot \alpha_{g n} \cdot R_{r n}^{*}}
$$

Temperature at the joint of $j$ and $j+1$ coating`s layers or coating`s layer and tuyere nose:

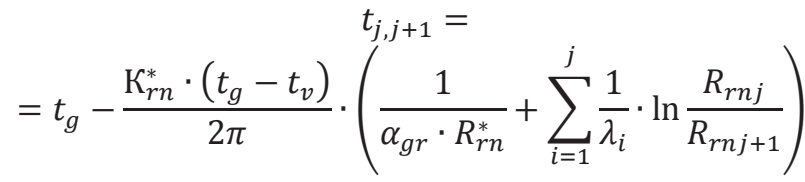

Temperature on the surface of tuyere nose from the side of water is:

$$
t_{r n-v}=t_{v}+\frac{K_{r n}^{*} \cdot\left(t_{g}-t_{v}\right)}{2 \pi \cdot \alpha_{v} \cdot\left(R_{r n}-h_{r}\right)}
$$
side:

- For cross-cut end of tuyere nose from the furnaces

Temperature on the surface of the first coating`s layer from the side of furnace is:

$$
t_{g-1}=t_{g}-\frac{\kappa_{r t} \cdot\left(t_{g}-t_{v}\right)}{\alpha_{g r}}
$$

Temperature at the joint of $j$ and $j+1$ coating`s layers or coating`s layer and tuyere nose:

$$
t_{j, j+1}=t_{g}-\kappa_{r t} \cdot\left(t_{g}-t_{v}\right) \cdot\left(\frac{1}{\alpha_{g r}}+\sum_{i=1}^{j} \frac{h_{i}}{\lambda_{i}}\right)
$$

Temperature on the surface of tuyere nose from the side of water is:

$$
t_{r t-v}=t_{v}+\frac{\mathrm{K}_{r t} \cdot\left(t_{g}-t_{v}\right)}{\alpha_{v}}
$$

- For internal nozzle:

Temperature on the surface of the first coating`s layer from the side of air passage is:

$$
t_{d-1}=t_{d}-\frac{\kappa_{v}^{*} \cdot\left(t_{d}-t_{v}\right)}{2 \pi \cdot \alpha_{d} \cdot R_{v}^{*}}
$$

Temperature at the joint of $j$ and $j+1$ coating`s layers or coating`s layer and internal nozzle:

$=t_{d}-\frac{\kappa_{v, j+1}^{*} \cdot\left(t_{d}-t_{v}\right)}{2 \pi} \cdot\left(\frac{1}{\alpha_{d} \cdot R_{v}^{*}}+\sum_{i=1}^{j} \frac{1}{\lambda_{i}} \cdot \ln \frac{R_{v j+1}}{R_{v j}}\right)$

Temperature on the surface of internal nozzle from the side of water is:

$$
t_{v-v}=t_{v}+\frac{K_{v}^{*} \cdot\left(t_{d}-t_{v}\right)}{2 \pi \cdot \alpha_{v} \cdot\left(R_{v}+h_{v}\right)}
$$

- For tuyere nose from the side of air passage:

Temperature on the surface of the first coating`s layer from the side of air passage is:

$$
t_{d-1}=t_{d}-\frac{\mathrm{K}_{r v}^{*} \cdot\left(t_{d}-t_{v}\right)}{2 \pi \cdot \alpha_{d} \cdot R_{r v}^{*}}
$$

Temperature at the joint of $\mathrm{j}$ and $\mathrm{j}+1$ coating`s layers or coating`s layer and tuyere nose:

$$
=t_{d}-\frac{\mathrm{K}_{r v}^{*} \cdot\left(t_{d}-t_{v}\right)}{2 \pi} \cdot\left(\frac{1}{\alpha_{d} \cdot R_{r v}^{*}}+\sum_{i=1}^{j} \frac{1}{\lambda_{i}} \cdot \ln \frac{R_{r v j+1}}{R_{r v j}}\right)
$$

Temperature on the surface of tuyere nose from the side of water is:

$$
t_{r v-v}=t_{v}+\frac{K_{r v}^{*} \cdot\left(t_{d}-t_{v}\right)}{2 \pi \cdot \alpha_{v} \cdot\left(R_{r v}+h_{r}\right)}
$$

By the calculation methods of heat losses through tuyere surface and temperature a linear excel program has been developed. With this program it was calculated the heat losses of blast tuyere's surface and temperature on tuyere's details for conditions DP-5 OJSC "NLMK". The values of heat-transfer coefficient had been calculated according to experimental data, were used [11].

We take $\mathrm{t}_{\mathrm{g}}=16000{ }^{\circ} \mathrm{C} ; \mathrm{t}_{\mathrm{d}}=11500{ }^{\circ} \mathrm{C} ; \mathrm{t}_{\mathrm{v}}=300{ }^{\circ} \mathrm{C} ; \mathrm{h}_{\mathrm{n}}$ $=7,0 \mathrm{~mm} ; \mathrm{h}_{\mathrm{r}}=16,0 \mathrm{~mm} ; \mathrm{h}_{\mathrm{rt}}=45,0 \mathrm{~mm} ; \mathrm{h}_{\mathrm{v}}=5,0 \mathrm{~mm} ; \mathrm{h}_{\mathrm{i}}=$ $1,5 \mathrm{~mm} ; \lambda_{C u}=415,6562 \mathrm{~W} /(\mathrm{m} \cdot \mathrm{K}) ; \lambda_{i}=29,8891 \mathrm{~W} /(\mathrm{m} \cdot \mathrm{K})$; $\alpha_{\mathrm{gn}}=\alpha_{\mathrm{gr}}=133,745 \mathrm{~W} /(\mathrm{m} 2 \cdot \mathrm{K}) ; \alpha_{\mathrm{d}}=465,2 \mathrm{~W} /\left(\mathrm{m}^{2} \cdot \mathrm{K}\right) ; \alpha_{\mathrm{b}}$ $=5815 \mathrm{~W} /\left(\mathrm{m}^{2} \cdot \mathrm{K}\right) ; \mathrm{R}_{\mathrm{nr}}=154 \mathrm{~mm} ; \mathrm{R}_{\mathrm{nf}}=185 \mathrm{~mm} ; \mathrm{R}_{\mathrm{nt}}=$ 
$140 \mathrm{~mm} ; \mathrm{R}_{\mathrm{vr}}=72,5 \mathrm{~mm} ; \mathrm{R}_{\mathrm{vf}}=72,5 \mathrm{~mm} ; \mathrm{R}_{\mathrm{vt}}=72,5 \mathrm{~mm}$; $\mathrm{H}_{\mathrm{n}}=305 \mathrm{~mm} ; \mathrm{H}_{\mathrm{rn}}=145 \mathrm{~mm} ; \mathrm{H}_{\mathrm{rv}}=167 \mathrm{~mm} ; \mathrm{H}_{\mathrm{v}}=283$ $\mathrm{mm}$.

Taking into account that the heat guard inside of air passage finds wide application $[12,13]$, it was a study on the thickness effects of insulation lining on heat losses through surface of air passage and it was obtained temperature distribution from water-cooled hole of tuyere to air passage (fig.2-3).

As a comparison, it was calculated heat losses through air passage with aluminum gas-thermal coating. Fig. 2 shows the presence of insulation lining has a significant effect on reduction of heat losses through air passage than application of aluminum coating. Creation of air gap between it and internal nozzle leads to additional reduction of heat losses. Besides, the more thickness of insulation lining, installed without gap in air passage, the less heat losses through air passage. If the insulation lining was installed with gap the thickness has little effect on heat losses through air passage.

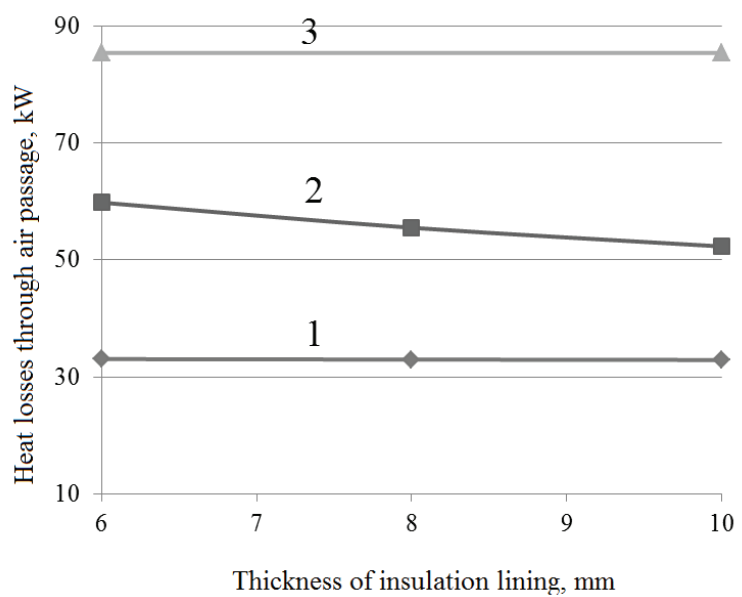

Fig. 2. Dependence of heat losses through air passage on thickness of insulation lining: $1-\mathrm{h}_{\mathrm{v}}=0,6 \mathrm{~mm} ; 2-\mathrm{h}_{\mathrm{v}}=0 \mathrm{~mm} ; 3-$ $\mathrm{h}_{\mathrm{Al}}=1,5 \mathrm{~mm} ; \lambda_{\text {inl. }}=3 \mathrm{~W} /(\mathrm{m} \cdot \mathrm{K}), \lambda_{\mathrm{v}}=0,0362 \mathrm{~W} /(\mathrm{m} \cdot \mathrm{K}), \lambda_{\mathrm{Al}}$ $=29,8891 \mathrm{~W} /(\mathrm{m} \cdot \mathrm{K})$

According to figure 3, it is observed the steep gradient of temperature between the insulation lining and internal nozzle in air gap via its low conductivity, so that the temperature of the insulation lining is higher and temperature of the internal nozzle is lower than in the absence of gap between them. In terms of lining's life the heavy gradient of temperatures on its thickness in the absence of gap may cause of the appearance of high thermoelastic stresses, expediting its destruction [14, 15].

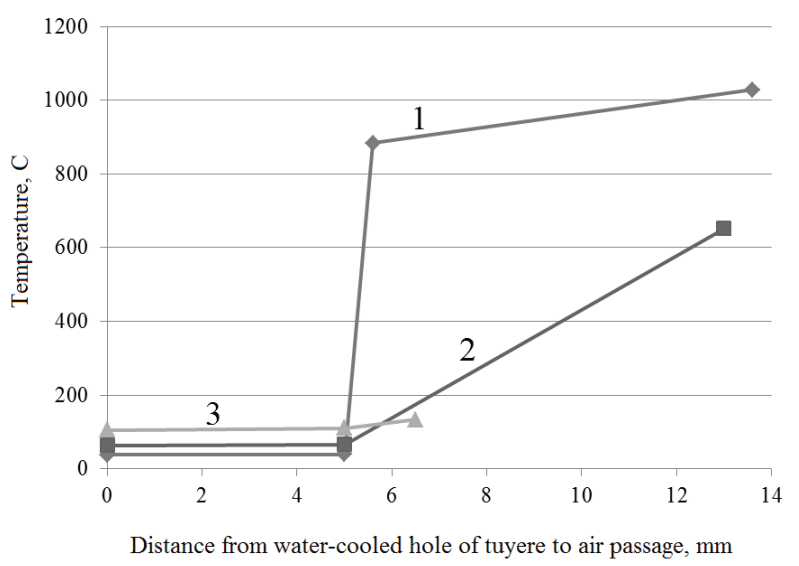

Fig. 3. Temperature distribution from water-cooled hole of tuyere to air passage: $\mathrm{h}_{\mathrm{v}}=5 \mathrm{~mm} ; 1-\mathrm{h}_{\mathrm{v}}=0,6 \mathrm{~mm}, \mathrm{~h}_{\text {inl }}=8 \mathrm{~mm} ; 2$ $\mathrm{h}_{\mathrm{v}}=0 \mathrm{~mm}, \mathrm{~h}_{\text {inl }}=8 \mathrm{~mm} ; 3-\mathrm{h}_{\mathrm{Al}}=1,5 \mathrm{~mm} ; \lambda_{\text {inl }}=3 \mathrm{~W} /(\mathrm{m} \cdot \mathrm{K})$, $\lambda_{\mathrm{v}}=0,0362 \mathrm{~W} /(\mathrm{m} \cdot \mathrm{K}), \lambda_{\mathrm{Al}}=29,8891 \mathrm{~W} /(\mathrm{m} \cdot \mathrm{K})$

\section{Conclusion}

The calculation technique of heat losses and temperature was adapted to blast furnaces tuyeres. Using a linear excel program the effect of gas-thermal coating and insulation lining on thermal state of the blast tuyere was studied.

\section{References}

1. A.V. Borodulin, A.P. Vasilev, E.L. Gluschenko and others, About heat losses of furnace cavity, The proceedings of the 2nd international research-topractice conference "Automatic furnace units and energy saving solutions in metallurgy”, 424 (2002)

2. V.N. Grigoriev, G.I. Urbanovich, E.G. Urbanovich and others, Pat. № 2215043 RF. IQR C21B7/16. Preparation setting up method of blast furnaces tuyere / - 20011337559/02; ass. 11.12.01, pub. 27.10.02 - Bul.№30

3. V.A. Akimov, avtoreferat dis. kand. tekh.nauk, Issledovanie $i$ sovershenstvovanie tekhnologii izgotovleniia vozdushnykh furm domennykh pechei naneseniem aliumosoderzhashchikh gazoplamennykh pokrytii s posleduiushchei termoobrabotkoi, 23 (2011)

4. A.G. Radyuk, A.E. Titlyanov, N.L. Kirillova, and others, Pat. 128614 RF, C21B7/16. Tuyere of blast furnace, №2013100964/02, pub. 27.05.13, Bul.№15

5. P.S. Bykovskikh, V.A. Tishchenko, S.V. Bykovskikh, Matematicheskaia model' teplovoi raboty vozdushnoi furmy domennoi pechi, Metall i lit'e Ukrainy, 4, 16 (2015)

6. E.B. Agapitov, V.A. Bolkunova, K.V. Shutov, Chislennoe modelirovanie teplovogo sostoianiia vodookhlazhdaemoi domennoi furmy pri nalipanii rasplava shlaka na ee poverkhnost, Vestnik MGTU im. G.I. Nosova, 4, 73 (2011)

7. V.V. Lavrov, N.A. Spirin, V.Yu Ribalovlev, Model study of temperature of blast furnace tuyere's wall, Not. Of HEI Ferrous metallurgy 2, 46 (2000) 
8. A.G. Manshilin, E.N. Skladanovsky, V.I. Necvetov and others, Pat. № 2235789 RF. IQR C21B7/16. Blast furnace's tuyere and technique of barrier coating's application on blast furnace tuyere, 2002129285/02, pub..27.05.04 - Bul.№15

9. V.P. Isachenko, V.A. Osipova, A.S. Sukomel, Teploperedacha, Energoizdat, 46 (1981)

10. S.S. Kutateladze, V.M. Borischansky, Heat-transfer reference, Gosenergopub, 414 (1959)

11. N.L. Kirillova, A.G. Radyuk, S.M. Gorbatyuk and others, Calculation of coefficients of heat-transfer to blast furnace tuyeres surfaces from forge to hot blow (Scein.-inform. publishing center "Institute for Strategic Studies", 132, 2012)

12. N.L. Kirillova, A.G. Radyuk, A.E. Titlyanov, Reducing heat losses through surface of blast furnace tuyere, Metallurgy 10, 28 (2013)

13. N.L. Kirillova, A.G. Radyuk, A.E. Titlyanov, S.M. Gorbatyuk, Improving air-tuyere operation in blast furnaces by means of coatings and sealant, Steel in Translation 5, 231 (2013)

14. K. Andreev, Kh. Kharmut, Raschet formirovaniia treshchin $v$ ogneuporakh, Fizicheskaia mezomekhanika 4, 109(2001)

15. L.M. Aksel'rod, A.V. Zabolotskii, Matematicheskoe modelirovanie razrusheniia futerovok metallurgicheskogo oborudovaniia pod deistviem termoudarov (Sb. n.tr. Sovremennaia nauka, 2010) 